\title{
OPTIMIZATION OF DOGBONING PHENOMENON OF THE CORONARY ARTERY STENT
}

\author{
Anita Ciekot ${ }^{1}$, Aneta Idziak-Jablońska ${ }^{2}$, Piotr Lacki ${ }^{3}$ \\ ${ }^{1}$ Institute of Mathematics, Czestochowa University of Technology, Poland \\ ${ }^{2}$ Institute of Mechanical Technologies, Czestochowa University of Technology, Poland \\ ${ }^{3}$ Faculty of Civil Engineering, Czestochowa University of Technology, Poland \\ anita.ciekot@im.pcz.pl,idziak.jablonska@gmail.com.pl,piotr@lacki.com.pl
}

\begin{abstract}
Optimization of the dogboning phenomenon of the coronary artery stent is the aim of the paper. The mathematical model for the slotted tube stent is formulated with the finite element analysis based on a parametric geometric model of stent. Some of the mechanical properties are examined: the expanding pressure, plastic strain, foreshortening and dogboning. This paper is focused on determination of the optimal parameters for lowest dogboning.
\end{abstract}

\section{Introduction}

One of the most important achievements in cardiosurgery, especially in treatment of myocardial ischaemia was stent implantation, which is called angioplasty. A stent is a tiny, wire meshed, tube-like metallic structure which is implanted to the narrow or blocked arteries in order to restore the blood perfusion to the heart muscle tissue $[1,2]$.

Generally, stents can be classified according to:

- construction:

- coil stents,

- ring stents,

- slotted tubes,

- mesh stents,

- compound stents,

- implantation method:

- balloon-expandable,

- self-expandable,

- shape:

- „I-stents” (implanted in stright sections of coronary vessels),

- "T-stents" (implanted in the places where the vessels join perpendicularly)

According to the required biomechanical properties the stents re-made of the following materials: 
- nitinol (RadiusTM, CardicoilTM, ParagonTM),

- platinum / iridium (AngiostentTM),

- $\operatorname{tantal}\left(\right.$ Wiktor ${ }^{\circledR}$, CordisTM, StreckerTM),

- gold (NIROYALTM),

- austenitic steel - Cr-Ni-Mo (DriverTM, VisionTM),

- titanium (TTS).

The design process of new stents and their evolution need to take into consideration biomechanical features such as: implantation and expansion procedure, stent materials and three-dimensional structures. The balloon-expandable stent socalled Palmaz-Schatz stent was analyzed for elaboration of the computational model [3], which is useful for finding the biomechanical response to changes of geometric parameters like: implantation pressure, dogboning, foreshortening, stresses and strain distribution in the stent. It is an important in terms of the effectiveness of the surgical procedure

\section{FEM implementation}

\subsection{Geometric model of the stent}

Geometry was modelled on the basis of Palmaz-Schatz stent. The length of the stent is $l=12 \mathrm{~mm}$, inner radius is $r=0.8 \mathrm{~mm}$, thickness ranges from 0.2 to $0.3 \mathrm{~mm}$ with thickness increment of $0.01 \mathrm{~mm}$. The stent geometry is shown in Figure 1 .

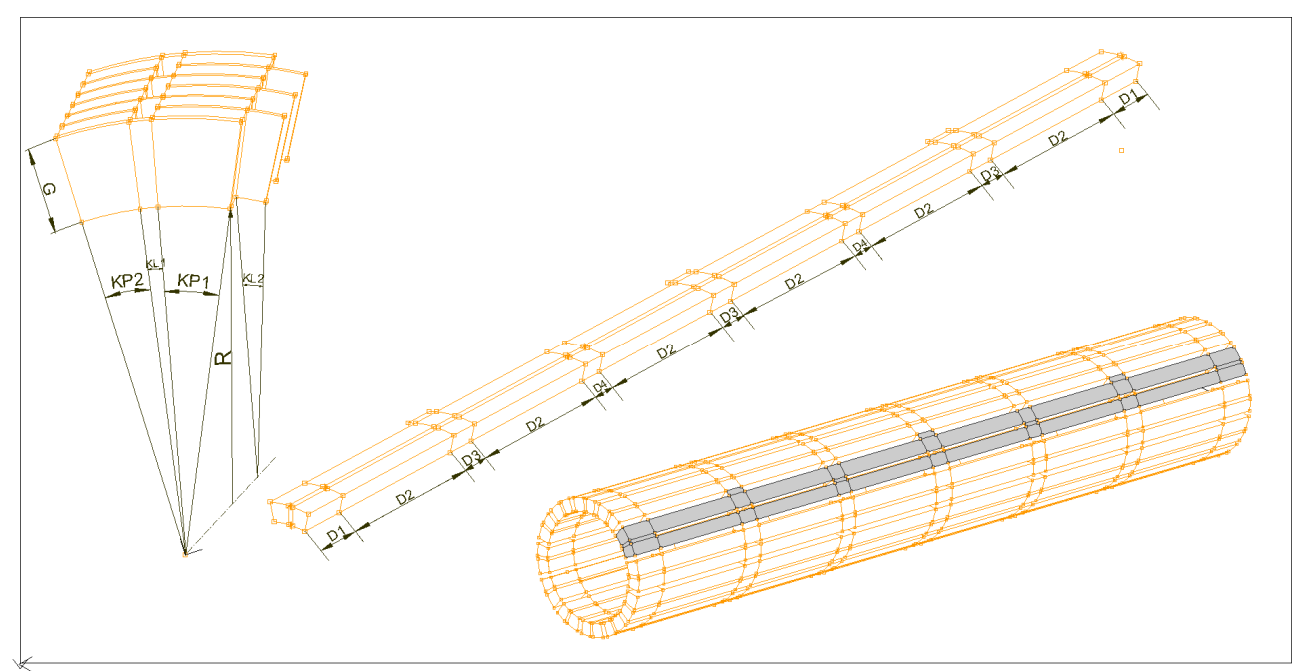

Fig. 1. Geometry of the stent. D1 $=0.5 \mathrm{~mm}, \mathrm{D} 2=1.6 \mathrm{~mm}, \mathrm{D} 3=0.3 \mathrm{~mm}, \mathrm{D} 4=0.25 \mathrm{~mm}$, $\mathrm{R}=0.8 \mathrm{~mm}, \mathrm{KP} 1=10^{\circ}, \mathrm{KP} 2=12^{\circ}, \mathrm{KL} 1=3^{\circ}, \mathrm{KL} 2=5^{\circ}$ 


\subsection{Meshing}

The meshing method was carried out using 3DSOLID elements. These are the parametric solid elements with 20 nodes and three degrees of freedom in each of them. The choice of such elements makes it possible to take into consideration the physical nonlinearity and large displacements and rotation. This model consists of 78480 nodes, $61203 \mathrm{D}$ elements in one segment. The total number of element is 73440. Numerical analysis was carried out using the ADINA System basing on finite element method $[4,5]$. Eleven simulations were carried out. The stent thickness was varied from 0.2 to 0.3 every $0.01 \mathrm{~mm}$. The geometric model of the stent with finite element meshes is shown in Figure 2a. The next stage in preparation of the model for numerical calculations was application of expanding pressure. According to the real operation conditions it was adopted that the pressure was put to the inner stent surface (see Fig. 2b).

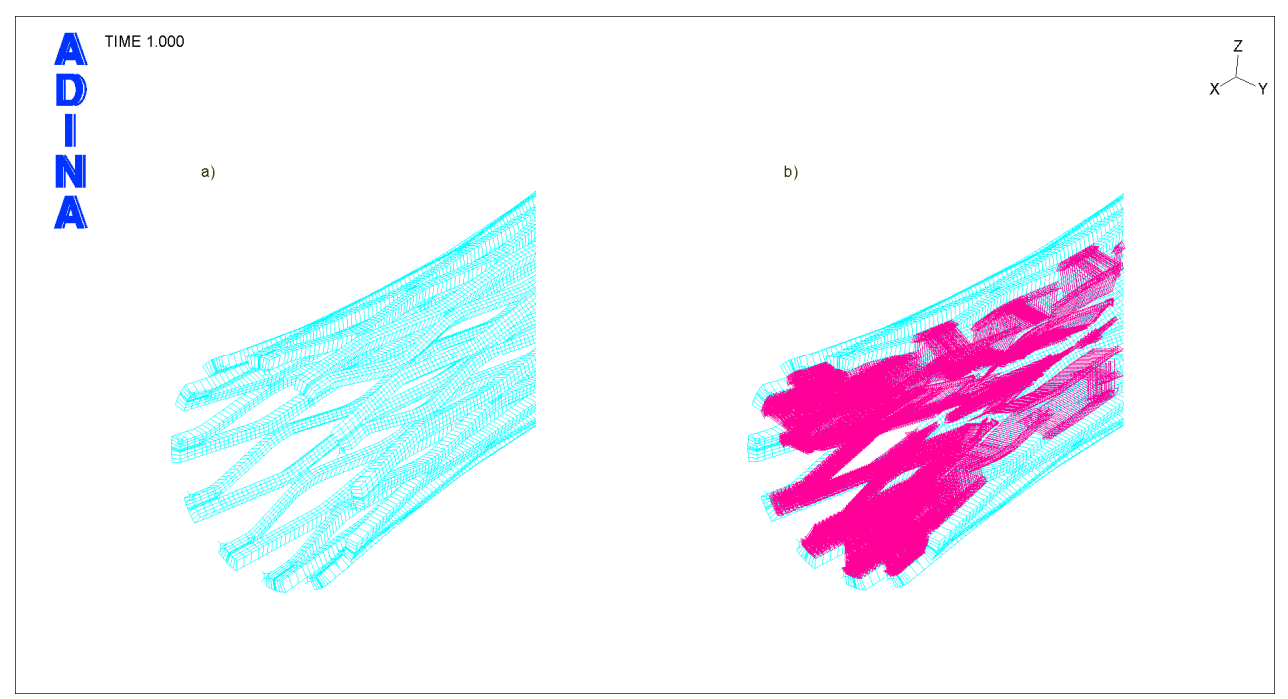

Fig. 2. Calculation model of the coronary stent: a) finite element mesh, b) distribution of pressure during expanding

\subsection{Materials}

The stent material model was simplified as bilinear elastic-plastic model with isotropic hardening. The following mechanical properties, which correspond to Cr-Ni-Mo steel, were assumed in the calculations:

- Young's modulus $E=205000 \mathrm{MPa}$,

- Poisson's ratio $v=0.33$,

- yield point $R_{p 0,2}=195 \mathrm{MPa}$, 
- tensile strength $R_{m}=470 \mathrm{MPa}$,

- maximl acceptable plastic strain $\varepsilon_{\max }=0.4$,

- density $\rho=7850 \mathrm{~kg} / \mathrm{m}^{3}$.

\section{Optimization model}

A selection of the optimal geometry is the main problem when designing a coronery artery stent. The stent geometry should ensure the lowest strains and stresses during its implantation and further work. According to former clinical studies a stent should have some mechanical properties so that the stent had: low pressure of expansion during implantation, high resistance against external pressure, low dogboning and limited foreshortening $\leq 2 \%$. These characteristics make the stent soft enough during the expansion but quite stiff during the recoil and compression. At the same time the stent must remain in an ideal shape under uniform radial pressure and keep the original longitudinal length with an acceptable level of shrinkage. This turns this problem into a multi-objective optimization problem $[6,7]$, and finding the optimal solution of such a task is very difficult and sometimes impossible without certain simplifications. At the beginning, we tried to simplify an objective function.

In this model of optimization the minimum of dogboning was considered. The value of thickness $-x_{1}$ and value of pressure $-x_{2}$, were the decision variables. These variables affect the value of the radius of the center $-D_{\text {central }}$ and the radius of the end of stent $-D_{\text {distal }}$. The objective function may be adopted in the form [8]:

$$
\text { Dogboning : }=\frac{D_{\text {distal }}-D_{\text {central }}}{D_{\text {central }}} \cdot 100 \%
$$

In addition, some constrains should be met: it was assumed that the shortening should not exceed $2 \%$, the wall thickness of the coronary artery should range between 0.2 and $0.3 \mathrm{~mm}$, and pressure: [0.4;0.7 MPa]. So the mathematical model of the optimization problem is presented as follows:

object : Dogboning : $=\frac{D_{\text {distal }}-D_{\text {central }}}{D_{\text {central }}} \cdot 100 \% \rightarrow$ Min

constraints: $\left\{\begin{array}{l}0.4 \leq x_{1} \leq 0.7 \\ 0.2 \leq x_{2} \leq 0.3 \\ \text { foreshortening }<2 \%\end{array}\right.$

$x_{i} \geq 0$

Finally, this model satisfied all demands for stent. 


\section{Results}

The functions describing the decision variables are given as the data in the form of measurement points obtained from the numerical simulation based on FEM (Table 1). The objective function (2) in the optimization problem is nonlinear and the optimization problem is the task of nonlinear programming $[9,10]$. Normally there is no analytic solution. In most cases the iterative methods are applied to solve this problem. For the discreetly specified functions, there are so called nongradient methods. These methods can be described as a one dimensional search methods based only on comparison the value of the objective function.

The coefficients of function decsribing the relationship between the decision variables and the radius of the center $-D_{\text {central }}$ and the radius at the end - $D_{\text {distal }}$ and the correlation coefficients were computed based on the data given in Table 1.

Table 1

Results of the numerical simulations

\begin{tabular}{|c|c|c|c|c|c|c|c|c|}
\hline \multirow[t]{2}{*}{$\begin{array}{c}\text { Stent } \\
\text { thickness } \\
G, \mathrm{~mm}\end{array}$} & \multirow[t]{2}{*}{$\begin{array}{c}\text { Pressure } \\
p, \mathrm{MPa}\end{array}$} & \multirow[t]{2}{*}{$\begin{array}{l}\mathrm{Z} \text { coordina- } \\
\text { te, } \mathrm{mm}\end{array}$} & \multicolumn{2}{|c|}{$\begin{array}{c}\text { Effective } \\
\text { stress, averag- } \\
\text { ing in node } \\
\sigma_{s r}, \mathrm{MPa} \\
\end{array}$} & \multirow[t]{2}{*}{$\begin{array}{c}\text { Strain } \\
\varepsilon, \%\end{array}$} & \multirow[t]{2}{*}{$\begin{array}{l}\text { Length } \\
L, \mathrm{~mm}\end{array}$} & \multirow[t]{2}{*}{$\begin{array}{l}\text { Foreshor- } \\
\text { tening, \% }\end{array}$} & \multirow[t]{2}{*}{$\begin{array}{c}\text { Dog- } \\
\text { boning } \\
\%\end{array}$} \\
\hline & & & MAX & MIN & & & & \\
\hline 0.2 & 0.4 & 1.983 & 317.5 & 2.74 & 0.163 & \multirow{11}{*}{12} & 2.183 & 27.935 \\
\hline 0.21 & 0.428 & 2.0 & 313.9 & 2.76 & 0.166 & & 0.7 & 26.662 \\
\hline 0.22 & 0.455 & 1.996 & 314.1 & 2.08 & 0.165 & & 0.7 & 25.219 \\
\hline 0.23 & 0.483 & 2.0 & 316.3 & 1.68 & 0.166 & & 0.658 & 24.069 \\
\hline 0.24 & 0.515 & 2.035 & 317.5 & 1.25 & 0.172 & & 1.95 & 23.408 \\
\hline 0.25 & 0.545 & 2.044 & 318.4 & 2.31 & 0.173 & & 2.125 & 22.469 \\
\hline 0.26 & 0.575 & 2.044 & 319.6 & 3.6 & 0.174 & & 0.658 & 21.378 \\
\hline 0.27 & 0.605 & 2.03 & 320.6 & 1.65 & 0.17 & & 1.967 & 20.261 \\
\hline 0.28 & 0.635 & 2.021 & 322.0 & 2.75 & 0.174 & & 0.95 & 19.233 \\
\hline 0.29 & 0.67 & 2.01 & 322.5 & 1.03 & 0.169 & & 1.083 & 18.305 \\
\hline 0.3 & 0.7 & 2.03 & 322.6 & 0.98 & 0.173 & & 2.533 & 17.341 \\
\hline
\end{tabular}

To find the minimum of the objective function the non-gradient method was used. The dogboning decreased fast at the beginning and in total, 10 iterations satisfy the conditions of the optimization model (Fig. 3) if the objective fuction depends on thickness. It is the same for expanding pressure.

Due to the shape of the objective function (fractional function) this nonlinear problem could be transformed to linear relatively easy and solved by the simplex method. The optimal solution, comparable with the solution obtained by iterative method, was already found in the fourth iteration. 


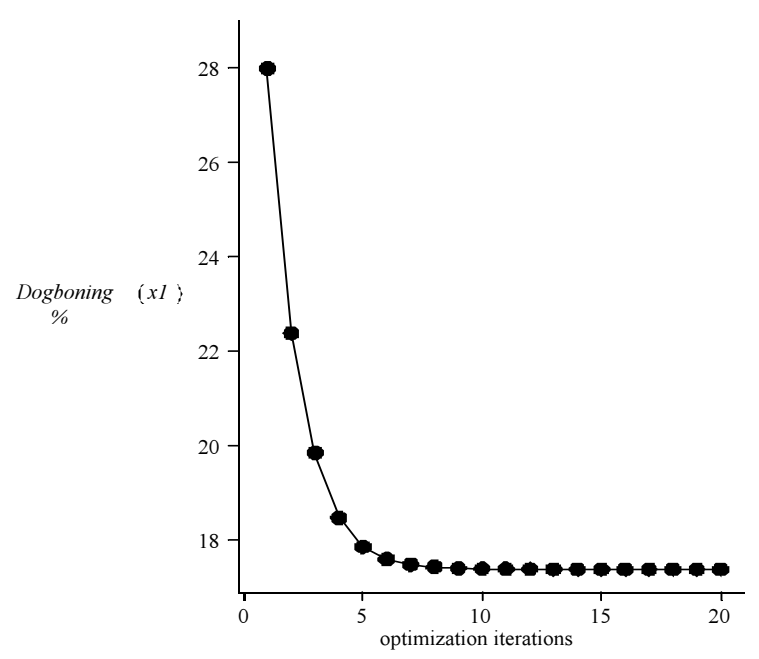

Fig. 3. Relationships of optimization iterations - dogboning

The evolution curve of the objective function - Dogboning is plotted in Figure 4. It fluctuates between 10 and 40 when the thickness and pressure are changed accordingly to optimization model conditions.

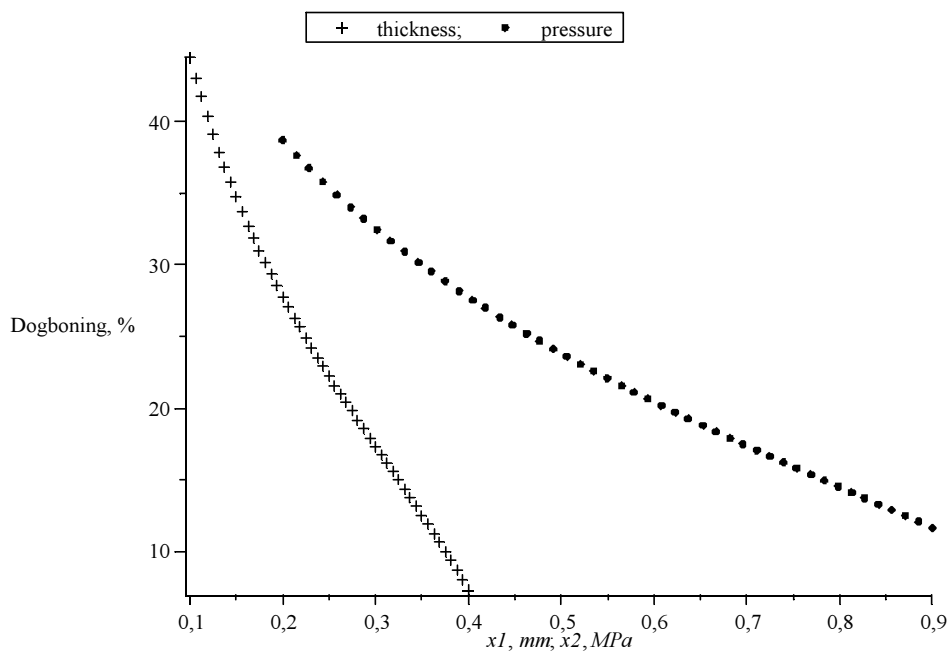

Fig. 4. Relationships of thikness (x1) and pressure (x2) - dogboning

\section{Conclusions}

According to the solution of the optimization problem it can be stated that the lowest value of stent diameter growth (17\%) appears for the stent thickness of 
$0.29 \mathrm{~mm}$ and expanding pressure $0.7 \mathrm{MPa}$. The demanded expansion pressure during stent implantation for the wall thickness of $0.2 \mathrm{~mm}$ was considerably lower than for the wall thickness of $0.3 \mathrm{~mm}$. The pressure was respectively $0.4 \mathrm{MPa}$ (for the wall thickness of $0.2 \mathrm{~mm}$ ) and $0.7 \mathrm{MPa}$ (for thickness of $0.3 \mathrm{~mm}$ ).

\section{References}

[1] Pochrząst M., Walke W., Kaczmarek M., Biomechanical characterization of the ballonexpandable slotted tube stents, Journal of Achievements in Materials and Manufacturing Engineering 2009, 2, 37, 340-347.

[2] Walke W., Paszenda Z., Jurkiewicz W., Biomechanical behaviour of coronary stent design with OCC techology, Journal of Achievements in Mechanical \& Materials Engineering. AMME 2007, 20, 1-2, January-February, 199-202.

[3] Walke W., Paszenda Z., Filipiak J., Experimental and numerical biomechanical analysis of vascular stent, 13 International Scientific Conference Achievements in Mechanical \& Materials Engineering AMME 2005, 699-703.

[4] Wei-Qiang Wang, Dong-Ke Liang, Da-Zhi Yang, Min Qi, Analysis of the transient expansion behavior and design optimization of coronary stents by finite element method, Journal of Biomechanics 2006, 39, 21-32.

[5] Zihui Xiaa, Feng Jua, Katsuhiko Sasaki, A general finite element analysis method for balloon expandable stents based on repeated unit cell (RUC) model. Finite Elements in Analysis and Design 2007, 43 649-658.

[6] Rodak M., Dwukryterialna optymalizacja belek cienkościennych kształtowanych na zimno o wybranych przekrojach otwartych, Modelowanie Inżynierskie 2011, 42, 351-358 (in Polish).

[7] Walke W., Paszenda Z., Marciniak J., Optymalizacja cech geometrycznych stentu wieńcowego z wykorzystaniem metody elementów skończonych, 12 International Scientific Conference Achievements in Mechanical \& Materials Engineering AMME 2003, 1011-1016 (in Polish).

[8] Ning Li, Hongwu Zhanga, Huajiang Ouyang, Shape optimization of coronary artery stent based on a parametric model, Finite Elements in Analysis and Design 2009, 45, 468-475.

[9] Findeisen W., Szymanowski J., Wierzbicki A., Teoria i metody obliczeniowe optymalizacji, PWN, Warszawa 1980 (in Polish).

[10] Luenberger D.G., Ye Y., Linear and Nonlinear Programing, Springer, New York 2007. 